\title{
INCIDENCE OF CONGENITAL MALFORMATIONS IN THE REGIONS OF ENGLAND AND WALES
}

\author{
PERCY STOCKS, C.M.G., M.D., F.R.C.P. \\ 34 Brompton Avenue, Colwyn Bay, North Wales
}

SugGrT attention was paid to the epidemiology of congenital malformations before the discovery that exposure of the mother to infection by rubella during early pregnancy could affect the development of the fetus (Gregg, 1941; Swan, Moore, Mayo and Black, 1943). Most malformations had been looked upon as inevitable happenings due to faults of development which were outside the scope of preventive medicine. Increasing use of $X$ rays during pregnancy and studies of background radiation then suggested that these might be concerned in initiating malformations, and in 1959 a study was published associating their incidence in parts of New York State with natural radiation from the ground (Gentry, Parkhurst and Bulin, 1959). Subsequent work has not, however, so far established the existence of any significant association with background radiation arising from either soil or water supply.

In 1968 Laurence, Carter and David reported a thorough investigation of the possible factors which might be concerned in the incidence of 835 cases of congenital malformation of the central nervous system discovered among births occurring during 1956-62 in the mining valleys of Glamorgan and Monmouth and the Vale of Glamorgan. Local variations in the incidence rates of such malformations were compared with geological features, water supplies, rainfall, sunshine, background radiation, radioactive fall-out and population density but none of these factors seemed to account for the differences. The only pregnancy factor with evident significance was an increased incidence of influenza.

The incidence rate per 1,000 live and stillbirths found in this South Wales survey for anencephaly, spina bifida and hydrocephalus malformations was 8.1 , similar to that found in Liverpool $(7 \cdot 4)$ by Smithells (1962) and in Belfast (8.3) by Stevenson and Warnock (1959). Lower incidence rates had been found in population surveys elsewhere.

A nation-wide survey of perinatal mortality resulting from 7,117 singleton births and comprising deaths in the first four weeks of life and stillbirths, which occurred in Great Britain in March to May 1958, was carried out by the National Birthday Trust (Butler and Bonham, 1963). This yielded some 500 congenital malformations of all kinds, but the total was insufficient for assessment of significant differences in incidence in the separate regions.

By the registration of causes of stillbirth based on certification according to the International List it becomes possible to bring together for each sex in 1963-66 the prenatal deaths from each kind of neuraltube malformation (rubrics $Y \mathbf{3 8 . 0}$ anencephaly, Y 38.1 hydrocephalus, Y 38.2 spina bifida), with all other congenital malformations ( $Y$ 38.3-Y 38.7) and postnatal deaths from corresponding causes at ages under 1 year and at 1-4 years in categories 750-752 and 753-759. In 1963-66 there were 24,458 stillbirths and deaths at $0-1$ year assigned to these numbers arising from three and a half million live and stillbirths in all, and the various rates for each sex have been calculated in the present paper for each Hospital Region in the hope that geographical variations will provide some clue to the causes of malformations, particularly those of the neural tube. The total incidence of malformations in infants is not fully revealed by the deaths classified to them as underlying cause, since some affected children die of concomitant causes and others continue to live with the disability, but within England and Wales, where the rules and procedure of certification are tolerably constant, one can assume that regional rates compounded of prenatal and postnatal deaths are comparable with each other though lower than total incidence rates derived from surveys.

In the final section of the paper the various regional distributions are compared with those for mortality of females from cardiovascular diseases, and other conditions for which there are indications of a 'water factor' apparently related to hardness of local water supplies (Morris, Crawford and Heady, 1961 ; Crawford, Gardner and Morris, 1968). 
Sex Ratios in Death Rates from Congenttal Malformations In 25 Countries

Before examining regional distributions of malformations in England and Wales there are some features of their geographical distribution in other countries which merit attention. The World Health Organisation has kindly supplemented their published data of death rates at 0-1 and 1-4 years of age per 1,000 live births for 1961-64 (W.H.O., 1967) by furnishing also the rates in 1965, making it possible the four Scandinavian countries have ratios below 0.86 . The most likely cause of a high female/male ratio in the death rates from all malformations at 0-1 year is a high proportion of those malformations of the central nervous system which affect females more than males, namely categories $750-752$ in the International List. Table I shows that this pro- $\frac{\vec{O}}{0}$ portion was $42 \%$ in Northern Ireland, about $39 \%$ 등 in Eire and Scotland, about $30 \%$ in England and $\bar{\sigma}$ Wales and Canada, and $27 \%$ in Germany and the

TABLE I

DEATH RATES FROM CONGENITAL MALFORMATIONS AT 0-1 YEAR PER 1,000 LIVE BIRTHS, AND SEX RATIOS IN 25 O COUNTRIES, 1961-65. NUMBERS AND PROPORTIONS OF DEATHS DUE TO CENTRAL NERVOUS SYSTEM AND OTHER

\begin{tabular}{|c|c|c|c|c|c|c|c|c|}
\hline \multirow{3}{*}{ Country } & \multirow{2}{*}{\multicolumn{2}{|c|}{$\begin{array}{l}\text { Rate under } \\
1 \text { year per } \\
1,000 \text { Live } \\
\text { Births }\end{array}$}} & \multirow{3}{*}{$\begin{array}{l}\text { Ratio of } \\
\text { Female to } \\
\text { Male } \\
\text { Rate }\end{array}$} & \multicolumn{5}{|c|}{ Analysis of Deaths at 0-1 yr. in 1961-64 } \\
\hline & & & & \multicolumn{2}{|c|}{ No. classed to } & \multirow{2}{*}{$\begin{array}{l}\text { C.N.S. } \\
\text { of } \AA \mathbf{l l}\end{array}$} & \multicolumn{2}{|c|}{$\begin{array}{r}\text { Sex-Ratios of } \\
\text { Rates (F/M) }\end{array}$} \\
\hline & $\mathbf{M}$ & $\mathbf{F}$ & & $\underset{t}{\text { C.SON.S. }}$ & $\underset{\text { 753-759 }}{\text { Other }}$ & & C.N.S. & Other \\
\hline $\begin{array}{l}\text { Northern Ireland } \\
\text { Scotland } \\
\text { Ireland (Eire) } \\
\text { Netherlands } \\
\text { England and Wales } \\
\text { Canada } \\
\text { Hungary } \\
\text { Germany F.R. } \\
\text { Belgium } \\
\text { Italy } \\
\text { Czechoslovakia } \\
\text { Israel } \\
\text { U.S.A. } \\
\text { Australia } \\
\text { Greece } \\
\text { Switzerland } \\
\text { Denmark } \\
\text { Japan } \\
\text { Norway } \\
\text { Austria } \\
\text { Venezuela } \\
\text { Finland } \\
\text { France } \\
\text { New Zealand } \\
\text { Sweden }\end{array}$ & $\begin{array}{l}582 \\
586 \\
695 \\
408 \\
435 \\
461 \\
676 \\
476 \\
488 \\
369 \\
470 \\
517 \\
379 \\
395 \\
352 \\
434 \\
454 \\
215 \\
364 \\
469 \\
196 \\
403 \\
399 \\
409 \\
362\end{array}$ & $\begin{array}{l}638 \\
613 \\
709 \\
400 \\
415 \\
438 \\
627 \\
435 \\
438 \\
330 \\
419 \\
458 \\
334 \\
345 \\
306 \\
376 \\
396 \\
184 \\
310 \\
398 \\
166 \\
338 \\
317 \\
303 \\
292\end{array}$ & $\begin{array}{l}1.096 \\
1.045 \\
1.020 \\
0.979 \\
0.955 \\
0.949 \\
0.927 \\
0.914 \\
0.898 \\
0.894 \\
0.889 \\
0.886 \\
0.881 \\
0.873 \\
0.869 \\
0.867 \\
0.856 \\
0.855 \\
0.852 \\
0.850 \\
0.848 \\
0.844 \\
0.815 \\
0.812 \\
0.806\end{array}$ & $\begin{array}{r}343 \\
846 \\
711 \\
1,096 \\
4,501 \\
2,748 \\
5, \overline{082} \\
742 \\
3,295 \\
840 \\
156 \\
778 \\
282 \\
428 \\
268 \\
1,101 \\
179 \\
450 \\
536 \\
336 \\
1,631 \\
210 \\
319\end{array}$ & $\begin{array}{r}477 \\
1,368 \\
1,102 \\
3,018 \\
10,159 \\
5,711 \\
13,744 \\
2,076 \\
11,307 \\
3,108 \\
739 \\
2,781 \\
1,695 \\
1,344 \\
1,081 \\
12,072 \\
682 \\
1,874 \\
1,950 \\
932 \\
10,746 \\
752 \\
1,165\end{array}$ & $\begin{array}{l}41 \cdot 8 \\
38 \cdot 1 \\
39 \cdot 2 \\
26 \cdot 6 \\
30 \cdot 7 \\
32 \cdot 5 \\
27 \cdot 0 \\
25 \cdot 4 \\
22 \cdot 6 \\
21 \cdot 3 \\
17 \cdot 4 \\
21 \cdot 9 \\
14 \cdot 2 \\
24 \cdot 2 \\
19 \cdot 9 \\
8 \cdot 4 \\
20 \cdot 8 \\
19 \cdot 4 \\
21 \cdot 3 \\
16 \cdot 5 \\
13 \cdot 2 \\
21 \cdot 8 \\
21 \cdot 5\end{array}$ & $\begin{array}{l}1 \cdot 67 \\
1.35 \\
1.51 \\
1.45 \\
1.47 \\
1.25 \\
1.22 \\
1.09 \\
1.14 \\
1.11 \\
0.09 \\
1 \cdot 16 \\
0.92 \\
1.09 \\
1.18 \\
0.95 \\
0.99 \\
1.43 \\
1.08 \\
1.13 \\
10.95 \\
1.19 \\
0.98\end{array}$ & $\begin{array}{l}0.74 \\
0.73 \\
0.73 \\
0.77 \\
0.73 \\
0.75 \\
0.77 \\
0.81 \\
0.74 \\
0.790 \\
0.82 \\
0.74 \\
0.77 \\
0.76 \\
0.75 \\
0.80 \\
0.74 \\
0.70 \\
0.76 \\
0.77 \\
0.72 \\
0.70 \\
0.70\end{array}$ \\
\hline
\end{tabular}

- Calculated from date tabulated by W.H.O. (1967)

†Anencephaly, spina bifida, hydrocephalus groups only

to show in Table I average annual rates for 25 countries. Although the death rates are subject to doubts as to precise comparability owing to differences in procedures of certification and selection of the underlying cause of death when other diseases were present, such differences would affect the two sexes in the same way and would not invalidate comparisons between the sex ratios recorded by the various countries.

In Fig. 1 the countries have been ranked in order of the female/male sex ratio of rates at $0-1$ year, and the ratios at $0-4$ years have also been shown alongside. The ratios range from 1.096 in Northern Ireland to 0.806 in Sweden, and it is noteworthy that the countries with ratios over 0.95 are the four parts of the British Isles and the Netherlands, whereas
Netherlands, with lower levels in other countries The correlation coefficient between this proportion o and the sex ratio at $0-1$ year is 0.82 , and, as will be seen in the next section, when prenatal and postnatal 을 deaths are compounded in the regions of England and Wales it is $\mathbf{0 . 7 2}$.

The last column of Table I shows only slight variation by country in the sex ratio between female $O$ and male rates at $0-1$ year for all other kinds of $N$ malformation, namely those in categories 753-759. N The range for these is from 0.82 to 0.70 whereas for $O$ the neural-tube malformations it is from 1.67 to 0.90 , with ranking of the countries similar to that for $\frac{}{\Phi}$ all malformations $(1.10$ to 0.81$)$ but more pro- $\stackrel{0}{\rightarrow}$ nounced. Thus the parts of Britain, the Netherlands and Austria show ratios exceeding 1.34, Canada, 


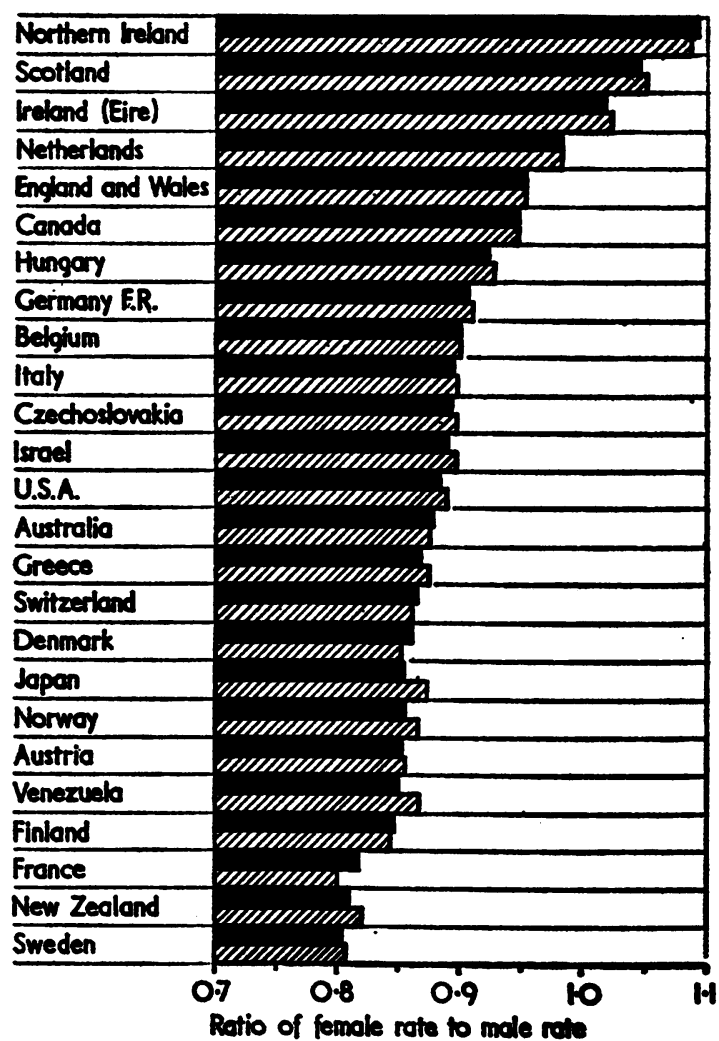

Fic. 1. Ratio of female to male mortality from congenital malformations at $0-1$ and $0-4$ years of age in 25 countries, 1957-66, based on numbers of live births of the sex in question. $0-1$ years $0-4$ years $1 / / / / /$

Australia, New Zealand, Germany and Denmark give ratios from $1 \cdot 25$ to $1 \cdot 18$, whilst Norway, Sweden, France, Japan, Greece and Israel have ratios below unity. The variations in ratios in the third and last two columns of the table cannot be explained by accidental factors such as differences in recording and classifying. Prenatal deaths could not be taken into account in this table owing to lack of data for most countries, but comparison with Table IV for England and Wales shows that inclusion of the stillborn increases the sex ratio for the central nervous system from 1.47 to 1.83 and for all malformations combined from 0.95 to $1 \cdot 20$. This is due to a higher proportion of fetal deaths among females affected by nervous system malformations than among males so affected, and this probably occurs in all countries. The remarkable feature is that the female excess among the liveborn infants with neural-tube anomalies is so much greater in the British Isles, the Netherlands and Canada than in Scandinavian countries.
The main conclusion from Table $I$ is that there must be some factor at work in the British Isles, and perhaps in the Netherlands, Canada and Germany, which tends to increase the incidence of congenital malformations of the neural tube among female infants, and this will be investigated further in the next sections where regional variations within England and Wales are considered.

Regional Distribution of Congenital

Malformations in England and Wales

The Registrar General uses two systems of division into regions: (1) Standard regions of which there were 11 in 1957-64 and 10 in 1965-66, of which 5 were subdivided into the conurbations and the remainder of the region (see footnote to Table II); (2) Hospital regions of which there are 15, with boundaries more suitable for hospital administration. Both systems have been used in the present

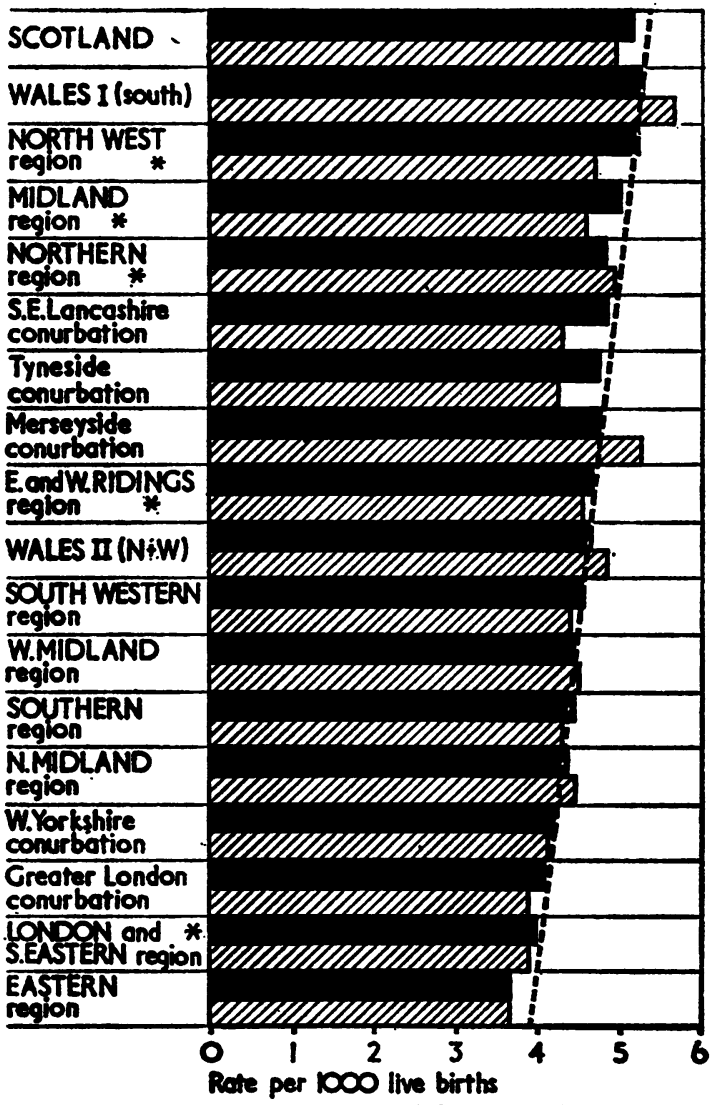

Fio. 2. Infant mortality of males and females attributed to congenital malformations in standard regions and conurbations of England and Wales, 1957-66, and in Scotland, 1963-66. ("Standard region excluding conurbations within it.)

$$
\text { Males }
$$


TABLE II

MEAN ANNUAL DEATHS FROM CONGENITAL MALFORMATIONS IN: MALES AND FEMALES AT AGES 0-1 AND 1-4 AND RATES PER 1,000 LIVE BIRTHS IN STANDARD REGIONS. AND CONURBATIONS, 1957-66*

\begin{tabular}{|c|c|c|c|c|c|c|c|c|c|c|}
\hline \multirow{2}{*}{ Standard Region } & \multicolumn{2}{|c|}{$\begin{array}{l}\text { Malformation } \\
\text { Deaths at } \\
\text { Age-period } \\
0-1 \text { year }\end{array}$} & \multicolumn{2}{|c|}{$\begin{array}{l}\text { Rates per } \\
1,000 \text { Live } \\
\text { Births at } \\
0-1 \text { year }\end{array}$} & \multicolumn{2}{|c|}{$\begin{array}{c}\text { No. of } \\
\text { Deaths at } \\
1-4 \\
\text { years }\end{array}$} & \multicolumn{2}{|c|}{$\begin{array}{l}\text { Addition } \\
\text { to Rate } \\
\text { at 0-1 year }\end{array}$} & \multicolumn{2}{|c|}{$\begin{array}{l}\text { Sex Ratio of } \\
\text { Female/Male } \\
\text { Rate at Age }\end{array}$} \\
\hline & $\mathbf{M}$ & $\mathbf{F}$ & $\mathbf{M}$ & $\mathbf{F}$ & $\mathbf{M}$ & $\mathbf{F}$ & $\mathbf{M}$ & $\mathbf{F}$ & $\begin{array}{c}0-1 \\
\text { year }\end{array}$ & $\begin{array}{l}0-4 \\
\text { years }\end{array}$ \\
\hline $\begin{array}{l}\text { Conurbations } \\
\text { Tyneside } \\
\text { South East Lancashire } \\
\text { Merseyside } \\
\text { West Yorkshire } \\
\text { West Midland } \\
\text { Greater London }\end{array}$ & $\begin{array}{r}874 \\
1,079 \\
680 \\
641 \\
989 \\
2,258\end{array}$ & $\begin{array}{r}325 \\
905 \\
709 \\
597 \\
938 \\
2,054\end{array}$ & $\begin{array}{l}4 \cdot 69 \\
4 \cdot 78 \\
4 \cdot 68 \\
4 \cdot 20 \\
4 \cdot 41 \\
4 \cdot 06\end{array}$ & $\begin{array}{l}4 \cdot 32 \\
4 \cdot 25 \\
5 \cdot 23 \\
4 \cdot 13 \\
4 \cdot 45 \\
3 \cdot 86\end{array}$ & $\begin{array}{r}30 \\
93 \\
72 \\
70 \\
100 \\
248\end{array}$ & $\begin{array}{r}20 \\
81 \\
48 \\
61 \\
87 \\
213\end{array}$ & $\begin{array}{l}0.38 \\
0.42 \\
0.49 \\
0.43 \\
0.45 \\
0.44\end{array}$ & $\begin{array}{l}0.26 \\
0.38 \\
0.24 \\
0.43 \\
0.41 \\
0.38\end{array}$ & $\begin{array}{l}0.92 \\
0.89 \\
1.12 \\
0.98 \\
1.01 \\
0.95\end{array}$ & $\begin{array}{l}0.90 \\
0.89 \\
1 \cdot 14 \\
0.96 \\
1.00 \\
0.95\end{array}$ \\
\hline $\begin{array}{l}\text { Standard region" } \\
\text { South-Western } \\
\text { Southern } \\
\text { London and South-Eastern† } \\
\text { Eastern } \\
\text { Northern† } \\
\text { Midland† } \\
\text { Wales I (south-east) } \\
\text { Wales II (rest) } \\
\text { North-Western } † \\
\text { East and West Ridingst } \\
\text { North Midland }\end{array}$ & $\begin{array}{r}1,274 \\
917 \\
737 \\
1,057 \\
1,082 \\
1,128 \\
865 \\
290 \\
1,235 \\
821 \\
1,156\end{array}$ & $\begin{array}{r}1,158 \\
850 \\
697 \\
920 \\
1,038 \\
986 \\
841 \\
252 \\
1,064 \\
761 \\
1,109\end{array}$ & $\begin{array}{l}4 \cdot 42 \\
4 \cdot 37 \\
3 \cdot 96 \\
3 \cdot 63 \\
4 \cdot 79 \\
4 \cdot 98 \\
5 \cdot 19 \\
4 \cdot 63 \\
5.13 \\
4 \cdot 64 \\
4 \cdot 34\end{array}$ & $\begin{array}{l}4 \cdot 37 \\
4 \cdot 25 \\
3.93 \\
3 \cdot 61 \\
4 \cdot 88 \\
4 \cdot 59 \\
5 \cdot 31 \\
4 \cdot 33 \\
4.70 \\
4 \cdot 54 \\
4 \cdot 45\end{array}$ & $\begin{array}{r}114 \\
103 \\
90 \\
124 \\
78 \\
103 \\
67 \\
26 \\
121 \\
61 \\
122\end{array}$ & $\begin{array}{r}153 \\
90 \\
91 \\
104 \\
77 \\
118 \\
80 \\
23 \\
98 \\
63 \\
96\end{array}$ & $\begin{array}{l}0.40 \\
0.49 \\
0.48 \\
0.43 \\
0.34 \\
0.45 \\
0.40 \\
0.42 \\
0.57 \\
0.34 \\
0.48\end{array}$ & $\begin{array}{l}0.20 \\
0.47 \\
0.57 \\
0.41 \\
0.36 \\
0.32 \\
0.50 \\
0.39 \\
0.43 \\
0.37 \\
0.38\end{array}$ & $\begin{array}{l}0.99 \\
0.97 \\
0.99 \\
0.99 \\
1.01 \\
0.92 \\
1.02 \\
0.93 \\
0.92 \\
0.98 \\
1.02\end{array}$ & $\begin{array}{l}0.99 \\
0.96 \\
1.01 \\
0.99 \\
1.02 \\
0.94 \\
1 \cdot 04 \\
0.93 \\
0.91 \\
0.96 \\
1.01\end{array}$ \\
\hline Scotland & 1,076 & 989 & $5 \cdot 12$ & $4 \cdot 97$ & & & & & 0.97 & \\
\hline
\end{tabular}

* In 1965-66 some regions were altered and the above refer to the regions as defined in 1957-64. It was not possible to obtain figures for 1965-66 for the Southern, London and South Eastern, Eastern, East and West Ridings and North Midland regions nor for Greater London, and the data in the table are for 1957-64 for those areas. Comparability of the mean annual rates and of the sex ratios is not affected appreciably.

t Excluding conurbations

study but the relevant data for the standard regions and conurbations are limited to the deaths by sex and age from total congenital malformations and the total live and stillbirths by sex, and these have been aggregated for the 10 years 1957-66. Since the numbers of stillborn with malformations are not tabulated for this series of regions by the Registrar General for the whole period, the rates at ages 0-1 and 1-4 in Table II represent deaths registered at those ages per 1000 live births for the sex in question.

For the Hospital Regions in 1963-66 more information has been obtained, including supplementary data by sex and separate cause for stillbirths (furnished by the Registrar General), making possible the calculation of rates per 1000 live and stillbirths shown in Tables III and IV.

Table II shows that the mean annual death rates of male infants from all congenital malformations in the six conurbations were highest in the northern areas of south-east Lancashire (4.78), Tyneside (4.69) and Merseyside (4.68), lower in the West Midlands (4.41) and West Yorkshire (4.20) conurbations and lowest in Greater London (4:06). In the standard regions excluding conurbations the male rates were highest in South Wales (Wales I) with 5.19 , and the North West $(5 \cdot 13)$, followed by the Midlands, Northern, East and West Ridings of Yorkshire and the rest of Wales. This is made clear in Fig. 2 which also shows that Scotland had a rate of about 5 as in the North West and Wales I. Male rates below 4.4 occur in the whole of the Eastern, South-Eastern and Southern regions, as well as in the North Midlands.

The rates for female infants have a similar distribution, exceeding 5 in Merseyside and South Wales and less than 4 in the Eastern and SouthEastern regions. Figure 2 shows that the female rate is much below that of males in South-East Lancashire and Tyneside conurbations and in the North-West and Midland regions, but the distribution is similar to that for males. The sex ratio of female to male mortality at $0-1$ year exceeds unity in Northern England, South Wales, North Midland regions and in Merseyside and West Midland conurbations, and is under 0.95 in the rest of Wales and in Tyneside conurbation and Midland and North-Western regions. As noted in the last section, the most likely reason for a high female excess would be a higher proportion than average of malformations of the neural tube. This possibility can be examined by analysing the hospital regional data for 1963-66 where combined live and stillbirth rates have been calculated.

Table III shows the mean annual death rates in 1963-66 in the 15 Hospital Regions (which incorporate the conurbations within those areas) based on the prenatal deaths occurring after the 28th week of pregnancy and postnatal deaths at 0-1 year for 
TABLE III

MEAN ANNUAL RATES OF MORTALITY BETWEEN THE 28th WEEK OF PREGNANCY AND 1 YEAR OF AGE PER 1,000 LIVE AND STILLBIRTHS CLASSED TO CONGENITAL MALFORMATIONS OF THE CENTRAL NERVOUS SYSTEM AND OTHER
PARTS OF THE BODY FOR EACH SEX IN HOSPITAL REGIONS, 1963-66

\begin{tabular}{|c|c|c|c|c|c|c|c|c|c|c|}
\hline \multirow{2}{*}{ Hospital Region } & \multicolumn{4}{|c|}{$\begin{array}{c}\text { Males } \\
\text { Mean annual rates, } 1963-66^{\circ}\end{array}$} & & \multicolumn{5}{|c|}{$\begin{array}{c}\text { Females } \\
\text { Mean annual rates, 1963-66 }\end{array}$} \\
\hline & $\mathbf{A}$ & B & C & $\mathbf{A}-\mathbf{C}$ & Other & $\mathbf{A}$ & B & $\mathbf{C}$ & A-C & Other \\
\hline $\begin{array}{l}\text { Liverpool } \\
\text { Welsh } \\
\text { Manchester } \\
\text { Newcastle } \\
\text { Wesex } \\
\text { Birmingham } \\
\text { Leeds } \\
\text { Sheffield } \\
\text { North-East Metropolitan } \\
\text { South-Western } \\
\text { South-East Metropolitan } \\
\text { East Anglia } \\
\text { Oxford } \\
\text { South-West Metropolitan } \\
\text { North-West Metropolitan }\end{array}$ & $\begin{array}{l}1 \cdot 58 \\
1.09 \\
1.48 \\
1 \cdot 23 \\
1 \cdot 12 \\
1 \cdot 14 \\
1 \cdot 08 \\
1 \cdot 11 \\
0.94 \\
1 \cdot 00 \\
0.93 \\
0.71 \\
0.91 \\
0.71 \\
0.80\end{array}$ & $\begin{array}{l}1.31 \\
1.81 \\
1.18 \\
0.82 \\
1.04 \\
0.79 \\
0.77 \\
0.57 \\
0.60 \\
0.78 \\
0.53 \\
0.49 \\
0.77 \\
0.53 \\
0.46\end{array}$ & $\begin{array}{l}0.71 \\
0.84 \\
0.74 \\
1.06 \\
0.73 \\
0.81 \\
0.60 \\
0.69 \\
0.69 \\
0.59 \\
0.56 \\
0.71 \\
0.45 \\
0.33 \\
0.52\end{array}$ & $\begin{array}{l}3 \cdot 60 \\
3 \cdot 67 \\
3 \cdot 40 \\
3 \cdot 21 \\
2 \cdot 89 \\
2 \cdot 74 \\
2 \cdot 45 \\
2 \cdot 37 \\
2 \cdot 23 \\
2 \cdot 37 \\
2 \cdot 02 \\
1.91 \\
2 \cdot 15 \\
1 \cdot 57 \\
1 \cdot 78\end{array}$ & $\begin{array}{l}3 \cdot 82 \\
3 \cdot 63 \\
3 \cdot 65 \\
3 \cdot 73 \\
3 \cdot 67 \\
3 \cdot 77 \\
4 \cdot 05 \\
4 \cdot 01 \\
4 \cdot 08 \\
3 \cdot 94 \\
3 \cdot 96 \\
3 \cdot 94 \\
3 \cdot 24 \\
3 \cdot 76 \\
3 \cdot 52\end{array}$ & $\begin{array}{l}3.95 \\
4.54 \\
3.52 \\
3.28 \\
2.44 \\
2.81 \\
3.08 \\
3.09 \\
1 \cdot 90 \\
2 \cdot 75 \\
2 \cdot 16 \\
2.42 \\
2.74 \\
1.93 \\
1.82\end{array}$ & $\begin{array}{l}1.97 \\
2.50 \\
1.55 \\
1.79 \\
1.13 \\
1.38 \\
1.09 \\
1.36 \\
1.24 \\
1.29 \\
0.90 \\
1.05 \\
1.35 \\
0.55 \\
0.96\end{array}$ & $\begin{array}{l}0.85 \\
0.73 \\
0.68 \\
0.88 \\
0.51 \\
0.58 \\
0.58 \\
0.65 \\
0.43 \\
0.56 \\
0.45 \\
0.53 \\
0.44 \\
0.43 \\
0.49\end{array}$ & $\begin{array}{l}6 \cdot 77 \\
7.77 \\
5 \cdot 75 \\
5 \cdot 95 \\
4 \cdot 08 \\
4 \cdot 77 \\
4 \cdot 75 \\
5 \cdot 03 \\
3 \cdot 57 \\
4 \cdot 60 \\
3 \cdot 51 \\
4 \cdot 00 \\
4 \cdot 53 \\
2 \cdot 91 \\
3 \cdot 27\end{array}$ & $\begin{array}{l}2.79 \\
2.63 \\
2.65 \\
3.02 \\
3.27 \\
2.53 \\
2.78 \\
2.92 \\
2.98 \\
2.96 \\
3.07 \\
3.36 \\
2.58 \\
2.64 \\
2.67\end{array}$ \\
\hline England and Wales & $1 \cdot 11$ & 0.81 & 0.68 & $2 \cdot 60$ & $3 \cdot 73$ & $2 \cdot 77$ & $1 \cdot 35$ & 0.59 & $4 \cdot 70$ & $2 \cdot 91$ \\
\hline
\end{tabular}

$A=$ Anencephaly $(\mathbf{3} 3 \cdot 0,750)$

$\mathrm{B}=$ Spina bifida (Y 38.2, 751)

C= Hydrocephalus (Y 38*1, 752)

Other = Remaining malformation groups (Y 38-3, 753, other nervous system and sense organs; $Y 38 \cdot 4-7,754-9$, other systems)

For totals of all congenital malformations, see first columns of Table IV

each sex per 1000 live and stillbirths. The malformations have been divided by cause into those due to the neural-tube anomalies-anencephaly, spina bifida and hydrocephalus (stillbirth rubrics Y 38.0, Y 38.2, Y 38.1 and infant mortality categories $750,751,752$ ) - and those due to other forms of malformation ( $Y$ 38.3 to $Y 38.7$ and 753-759). Table IV expresses the groups as percentages of all malformations and shows the sex ratios for each of the two groups.
The regions are ranked in order of the total rate for males, as also in Figure 3 where the excess of female over male rates arising from inclusion of the prenatal deaths is seen in every region. The male rate is over 6.85 per 1000 live and stillbirths in Scotland and in the Liverpool, Welsh, Manchester and Newcastle regions, and rates under 5.85 occur in the Western Metropolitan regions and in Oxford. For females the geographical distribution is similar, with high rates of 8.4 or more in the Northern areas,

TABLE IV

RATES OF MORTALITY FROM ALL CONGENITAL MALFORMATIONS PER 1,000 LIVE AND STILLBIRTHS FOR EACH SEX, PROPORTIONS AFFECTING THE CENTRAI NERVOUS AND OTHER SYSTEMS, WITH SEX RATTOS OF FEMALE TO MALE RATE, IN HOSPITAL REGIONS, 1963-66

\begin{tabular}{|c|c|c|c|c|c|c|c|c|c|}
\hline \multirow{3}{*}{ Hospital Regions and Scotland } & \multirow{2}{*}{\multicolumn{2}{|c|}{$\begin{array}{l}\text { Total Rates } \\
\text { for All } \\
\text { Malformations }\end{array}$}} & \multirow{2}{*}{\multicolumn{3}{|c|}{$\begin{array}{l}\text { Percent in Groups } \\
\text { A, B, C (A-C) of the } \\
\text { Nervous System }\end{array}$}} & \multicolumn{4}{|c|}{ Sex Ratios of Rates } \\
\hline & & & & & & \multirow{2}{*}{$\begin{array}{c}\text { All } \\
\text { Forms } \\
\text { F/M } \\
\end{array}$} & \multirow{2}{*}{$\begin{array}{c}\text { Group } \\
\text { A-C } \\
\mathbf{F} / \mathbf{M}\end{array}$} & \multirow{2}{*}{$\begin{array}{l}\text { Other } \\
\text { F/M }\end{array}$} & \multirow{2}{*}{$\begin{array}{l}\text { Deaths } \\
\text { at } 0_{-1} \\
\mathrm{~F} / \mathrm{M}^{*}\end{array}$} \\
\hline & $\mathbf{M}$ & $\mathbf{F}$ & $\mathbf{M}$ & $\mathbf{F}$ & $\mathbf{M}+\mathbf{F}$ & & & & \\
\hline $\begin{array}{l}\text { Liverpool } \\
\text { Welah } \\
\text { Manchester } \\
\text { Newcastle } \\
\text { Wessex } \\
\text { Birmingham } \\
\text { Leeds } \\
\text { Sheffield } \\
\text { North-East Metropolitan } \\
\text { South-Western } \\
\text { South-East Metropolitan } \\
\text { East Anglia } \\
\text { Oxford } \\
\text { South-West Metropolitan } \\
\text { North-West Metropolitan }\end{array}$ & $\begin{array}{l}7 \cdot 42 \\
7 \cdot 20 \\
7 \cdot 05 \\
6 \cdot 93 \\
6 \cdot 56 \\
6 \cdot 51 \\
6 \cdot 50 \\
6 \cdot 38 \\
6 \cdot 31 \\
6 \cdot 11 \\
5 \cdot 98 \\
5 \cdot 85 \\
5 \cdot 37 \\
5 \cdot 33 \\
5 \cdot 30\end{array}$ & $\begin{array}{r}9 \cdot 56 \\
10 \cdot 40 \\
8 \cdot 40 \\
8 \cdot 97 \\
7.35 \\
7 \cdot 30 \\
7.53 \\
7 \cdot 95 \\
6.55 \\
7.55 \\
6.58 \\
7.56 \\
7.31 \\
5.55 \\
5.96\end{array}$ & $\begin{array}{l}48 \cdot 5 \\
51 \cdot 0 \\
48 \cdot 2 \\
46 \cdot 3 \\
44 \cdot 1 \\
42 \cdot 1 \\
37 \cdot 7 \\
37 \cdot 1 \\
35 \cdot 3 \\
38 \cdot 6 \\
33 \cdot 4 \\
32 \cdot 6 \\
40 \cdot 0 \\
29 \cdot 5 \\
33 \cdot 6\end{array}$ & $\begin{array}{l}71 \cdot 0 \\
74 \cdot 7 \\
68 \cdot 4 \\
66 \cdot 3 \\
55 \cdot 5 \\
61 \cdot 2 \\
63 \cdot 1 \\
63 \cdot 3 \\
54 \cdot 5 \\
60 \cdot 9 \\
53 \cdot 3 \\
54 \cdot 3 \\
62 \cdot 0 \\
52 \cdot 4 \\
54 \cdot 9\end{array}$ & $\begin{array}{l}60 \cdot 5 \\
67 \cdot 3 \\
59 \cdot 0 \\
58 \cdot 6 \\
50 \cdot 0 \\
52 \cdot 7 \\
48 \cdot 2 \\
51 \cdot 2 \\
44 \cdot 8 \\
50 \cdot 9 \\
44 \cdot 3 \\
44 \cdot 3 \\
53 \cdot 3 \\
40 \cdot 8 \\
45 \cdot 6\end{array}$ & $\begin{array}{l}1 \cdot 29 \\
1.44 \\
1 \cdot 19 \\
1 \cdot 29 \\
1 \cdot 12 \\
1 \cdot 20 \\
1 \cdot 17 \\
1.25 \\
1.04 \\
1.24 \\
1 \cdot 10 \\
1.28 \\
1.38 \\
1.04 \\
1 \cdot 12\end{array}$ & $\begin{array}{l}1 \cdot 88 \\
2 \cdot 12 \\
1 \cdot 69 \\
1.85 \\
1.41 \\
1.74 \\
1 \cdot 94 \\
2 \cdot 12 \\
1.60 \\
1.94 \\
1.74 \\
2.09 \\
2.12 \\
1.86 \\
1.89\end{array}$ & $\begin{array}{l}0.73 \\
0.72 \\
0.73 \\
0.81 \\
0.89 \\
0.67 \\
0.69 \\
0.73 \\
0.73 \\
0.75 \\
0.77 \\
0.85 \\
0.80 \\
0.69 \\
0.76\end{array}$ & $\begin{array}{l}0.95 \\
1.00 \\
0.84 \\
0.98 \\
0.94 \\
0.95 \\
0.89 \\
0.93 \\
0.89 \\
0.93 \\
0.88 \\
0.88 \\
1.00 \\
0.79 \\
0.84\end{array}$ \\
\hline England and Wales & $6 \cdot 33$ & $7 \cdot 61$ & $41 \cdot 1$ & $61 \cdot 8$ & $52 \cdot 2$ & $1 \cdot 20$ & $1 \cdot 83$ & 0.75 & 0.91 \\
\hline Scotland & $7 \cdot 76$ & $10 \cdot 77$ & $46 \cdot 5$ & 66.7 & $57 \cdot 9$ & 1.41 & 1.99 & 0.87 & 0.98 \\
\hline
\end{tabular}

-Ratio for death rates at 0-1 year per 1,000 live births (all forms of malformation) 


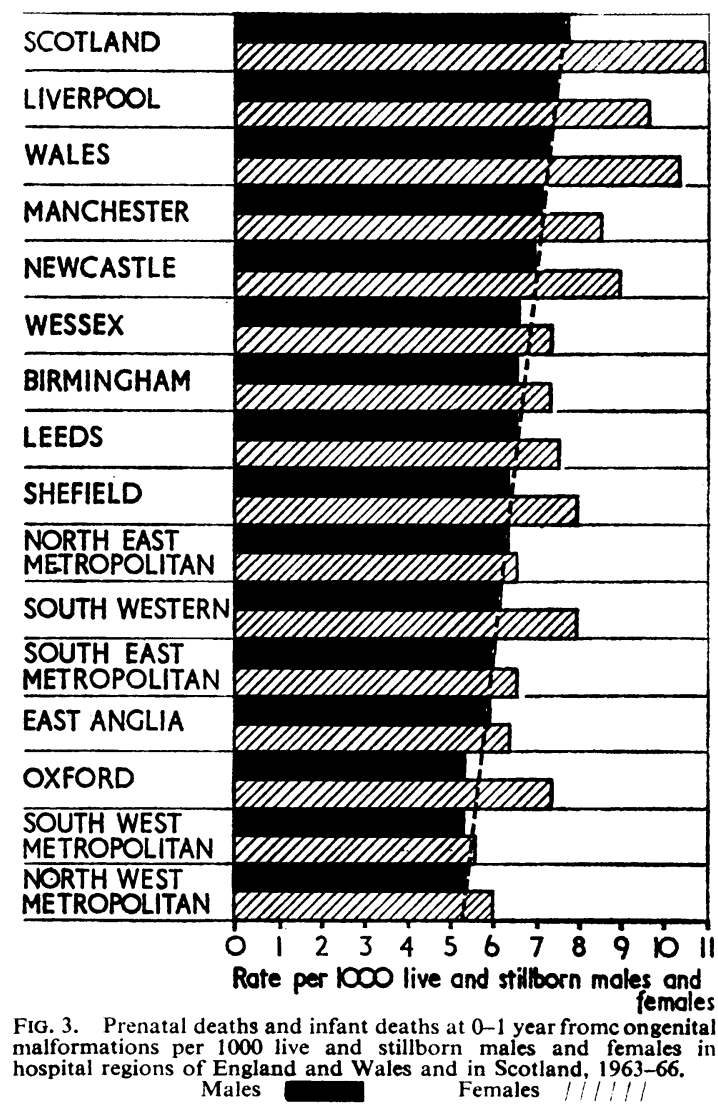

Scotland and Wales and rates below 7 in the Metropolitan regions. Figure 3 shows that the largest female excess occurs in Scotland and in the Welsh, Liverpool, Newcastle, Manchester, Oxford, Sheffield and South-West regions, and in Table IV it is seen that the sex ratio between female and male rates for all malformations combined ranges from 1.44 in Wales to values from 1.04 to 1.12 in the Metropolitan regions and Wessex.

Regional Differences in Rates According to NATURE OF MALFORMATION

The total prenatal and postnatal deaths in England

TABLE V

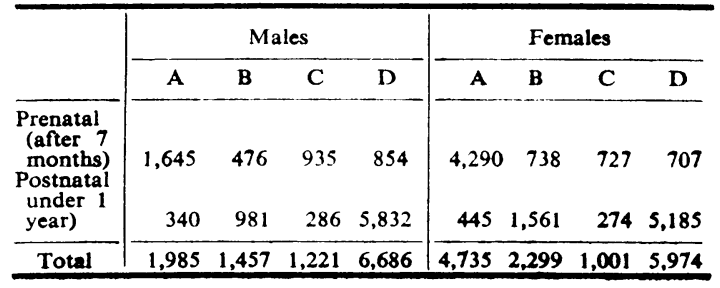

and Wales during 1963-66 from the various types of congenital malformation as defined in Tables III and IV are shown in Table V.

In Table III, where the regions are ranked in descending order of the male rate for all malformations (see the first column of Table IV) it is seen that the rates for the three divisions of the central nervous system $(A, B, C)$ all show a ranking similar to that of the total malformations. Group A rates for males (anencephaly) are highest in the North and North-West (over 1.2) and lowest in the Metropolitan regions, East Anglia and Oxford (under 0.95 ), and for females they are highest in the North, North-West and Wales (over 3.2) and lowest in the Metropolitan regions (under 2.2). In group B (spina bifida) male rates are highest in the North, North-West, Wales and Wessex (over 0.9) and lowest in the Metropolitan, East Anglia and Sheffield regions (under 0.61 ), and female rates are highest in the North, North-West and Wales (over 3.2) and lowest in three of the Metropolitan regions and East Anglia (under 1.06). In group $C$ (hydrocephalus) male rates are highest in the North, NorthWest, Wales, Birmingham and Wessex (over 0.72) and lowest in three Metropolitan regions and Oxford (under 0.57), and female rates are highest in the North, North-West and Wales (over 0.67) and lowest in the Metropolitan and Oxford regions. The three central nervous groups therefore have a strong north-west to south-east downward trend in mortality for each sex.

In contrast to this the group of all other congenital malformations shows no variation in regional rates which could not be explained by chance. Thus, for the first four regions in the table the average rates are 3.68 for males and 2.77 for females, and for the last four they are 3.62 for males and 2.82 for females. It can be concluded from this that the factors responsible for the regional distribution in Fig. 3 affect only malformations of the central nervous system and not other forms.

Table IV also shows that the percentage of groups A-C (neural tube) in the total malformations of both sexes ranged from 67 in Wales and about 59 in the North and North-West to less than 45 in the Metropolitan regions and East Anglia. The ranking of the percentages agrees rather closely with that of the sex ratio of death rates at 0-1 year from all forms of malformation, the correlation coefficient being +0.72 . Almost the same correlation $(+0.71)$ was found between the percentage of central nervous groups (750-752) among the deaths from all malformations at $0-1$ year and the sex ratio of the total death rate (for groups $750-759$ ) in 23 countries as already noted. 
FACTORS UNDERLying THE Differences In REgIONAL INCIDENCE OF MALFORMATIONS

The regional distribution of the rates of combined prenatal and postnatal mortality (under 1 year) from congenital malformations of the central nervous system, shown in Fig. 4 as the mean rates distributions closely resembling Fig. 4 are found for cardiovascular diseases, and, though the correspondence is not so close, for nephritis, bronchitis and stomach cancer also.

In early studies of geographical pathology climatic factors were blamed for the northerly

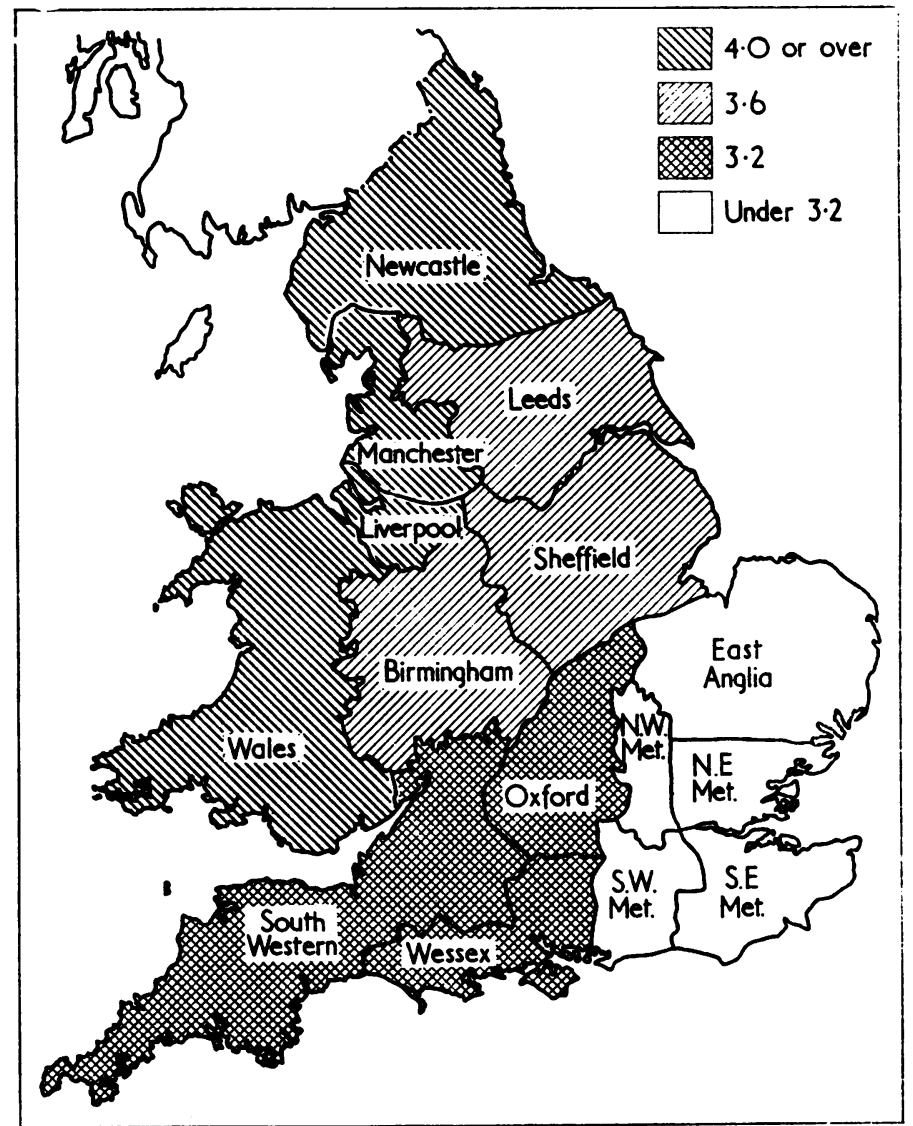

Fio. 4. Map of hospital regions of England and Wales showing distribution of mortality between the 28th week of pregnancy and 1 year of age per 1000 live and stillbirths classed to congenital malformations of the central nervous system (groups A-C) 1963-66. (Mean of rates for males and females.)

for males and females, divides the country into a high-rate area in the North, North-West and Wales, a low-rate area south and east of a line from the Wash to the Bristol Channel and an intermediate midland zone together with Leeds. Table IV shows that this applies to rates for the central nervous defects in groups $\mathrm{A}-\mathrm{C}$ but not to other malformations which exhibit no significant regional differences. There must be some factor or factors to account for this contrast and a point to notice is that excess of mortality in general in England, and later air pollution was implicated for respiratory diseases, but these would not account for the high rates for many causes in Wales unless high rainfall was a factor. Epidemiological studies of cancer drew attention to the high incidence of gastric cancer in Wales and to the possibility that some constituents of water supplies might be responsible (Stocks, 1947, 1950). The geological map sketched in Fig. 5 helps to explain why hardness of water tends to be 


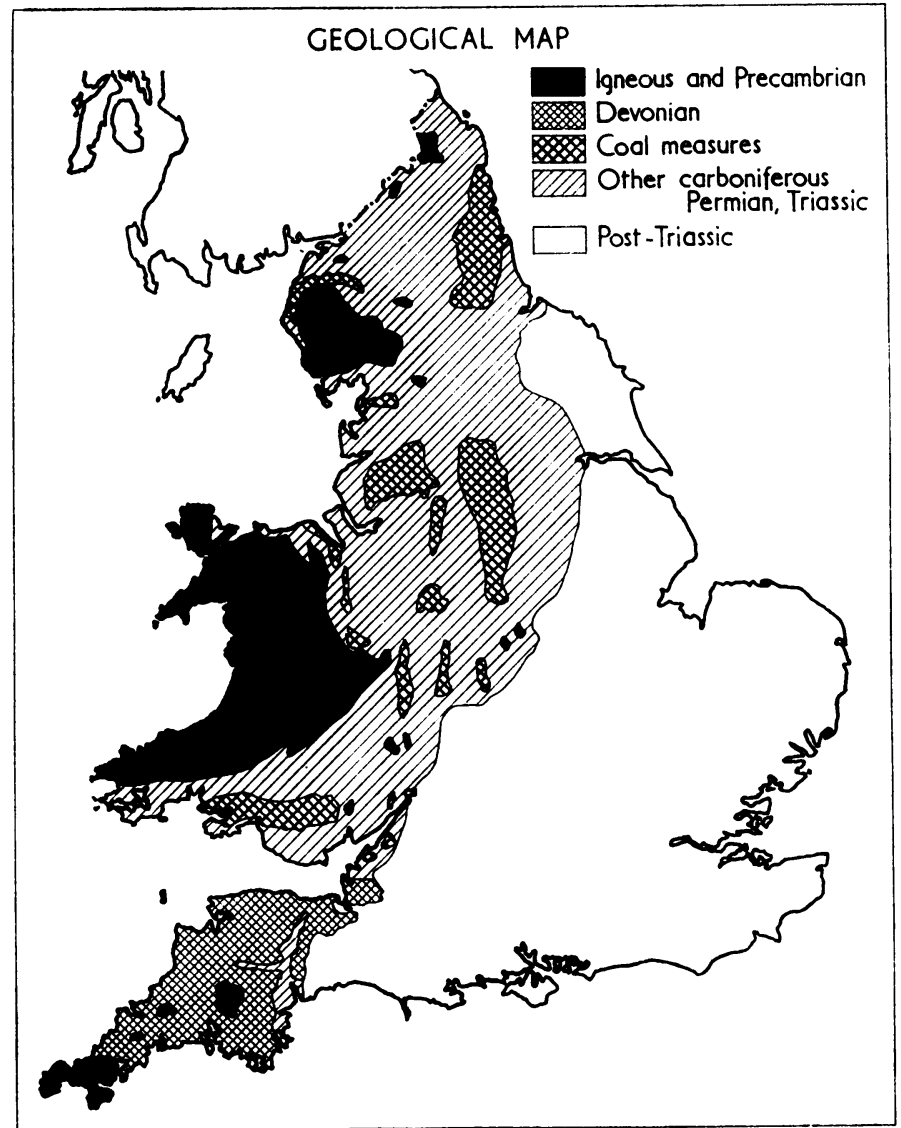

Fic. 5. Geological map showing general distribution of outcropping strata according to age.

TABLE VI

DEATH RATES OF FEMAIES AGED 25-54 IN 1963-66 FROM CARDIOVASCULAR DISEASES, NEPHRITIS, STOMACH CANCER, BRONCHITIS AND ALL OTHER CAUSES IN HOSPITAL REGIONS OF ENGLAND AND WALES

\begin{tabular}{|c|c|c|c|c|c|c|c|c|}
\hline \multirow{2}{*}{$\begin{array}{l}\text { Hospital Regions } \\
\text { (ranked by malformation rates } \\
\text { of males as in Table IV) }\end{array}$} & \multicolumn{7}{|c|}{ Mean Annual Rates per Million in 1963-66 } & \multirow[b]{2}{*}{$\begin{array}{c}\text { All } \\
\text { Other } \\
\text { Causes }\end{array}$} \\
\hline & $\begin{array}{l}\text { Chronic } \\
\text { Rheumatic } \\
\text { Heart }\end{array}$ & $\begin{array}{c}\text { Coronary } \\
\text { Disease }\end{array}$ & $\begin{array}{c}\text { Other } \\
\text { Heart } \\
\text { Disease }\end{array}$ & $\begin{array}{c}\text { Vascular } \\
\text { Lesions } \\
\text { of C.N.S. }\end{array}$ & $\begin{array}{c}\text { Nephritis } \\
\text { and } \\
\text { Nephrosis }\end{array}$ & $\begin{array}{c}\text { Stomach } \\
\text { Cancer }\end{array}$ & Bronchitis & \\
\hline $\begin{array}{l}\text { Liverpool } \\
\text { Welsh } \\
\text { Manchester } \\
\text { Newcastle } \\
\text { Wessex } \\
\text { Birmingham } \\
\text { Leeds } \\
\text { Sheffield } \\
\text { North-East Metropolitan } \\
\text { South-Western } \\
\text { South-East Metropolitan } \\
\text { East Anglia } \\
\text { Oxford } \\
\text { South-West Metropolitan } \\
\text { North-West Metropolitan }\end{array}$ & $\begin{array}{r}188 \\
179 \\
174 \\
152 \\
82 \\
115 \\
141 \\
139 \\
114 \\
97 \\
92 \\
57 \\
77 \\
90 \\
89\end{array}$ & $\begin{array}{l}228 \\
213 \\
234 \\
236 \\
122 \\
146 \\
190 \\
159 \\
141 \\
139 \\
130 \\
113 \\
120 \\
123 \\
128\end{array}$ & $\begin{array}{l}92 \\
86 \\
87 \\
72 \\
68 \\
74 \\
53 \\
72 \\
46 \\
59 \\
71 \\
57 \\
60 \\
45 \\
49\end{array}$ & $\begin{array}{l}216 \\
228 \\
253 \\
226 \\
165 \\
213 \\
192 \\
191 \\
161 \\
210 \\
167 \\
167 \\
154 \\
166 \\
155\end{array}$ & $\begin{array}{l}27 \\
36 \\
28 \\
32 \\
23 \\
30 \\
28 \\
32 \\
24 \\
29 \\
22 \\
21 \\
18 \\
24 \\
20\end{array}$ & $\begin{array}{l}61 \\
50 \\
59 \\
65 \\
48 \\
50 \\
56 \\
51 \\
51 \\
42 \\
36 \\
38 \\
49 \\
41 \\
41\end{array}$ & $\begin{array}{l}69 \\
52 \\
82 \\
73 \\
29 \\
54 \\
67 \\
63 \\
37 \\
35 \\
37 \\
31 \\
29 \\
35 \\
34\end{array}$ & $\begin{array}{l}168 \\
166 \\
176 \\
168 \\
162 \\
169 \\
167 \\
155 \\
156 \\
167 \\
175 \\
152 \\
147 \\
174 \\
175\end{array}$ \\
\hline Mean regional rates & 119 & 161 & 66 & 191 & 26 & 49 & 49 & 165 \\
\hline
\end{tabular}

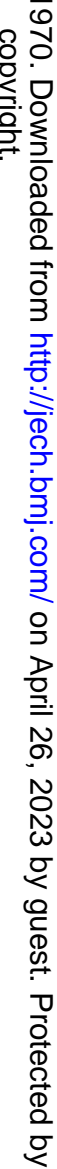


greater in the south and east than in the north and west and Morris et al. (1961, 1962), and more recently Crawford et al. (1968), demonstrated the surprising fact that mortality from most cardiovascular diseases in the county boroughs was strongly associated with softness of their water supplies and negatively correlated with the amounts of calcium present. A very careful search was made for other social and chemical factors which might account for this but nothing definite emerged except the 'water factor' and an ill-defined 'latitude' factor. Calculation of water indices characterizing whole regions would be difficult owing to the number of local sources involved, and it is only possible to postulate that differences between such indices in respect of the amount of one constituent might account for the curious distributions of mortality.

In Table VI the mean annual death rates of women aged 25-54 during 1963-66 are given for causes of death whose regional frequency pattern resembles that for congenital malformations of the central nervous system in Figure 4. Such causes fall into the following groups comprising the international categories shown in parentheses:

\section{Cardiovascular}

Chronic rheumatic heart disease (410-416)

Coronary disease (420)

Other degenerative, hypertensive and ill-defined heart disease (421-443)

Vascular disease of central nervous system (330-334)

\section{Other diseases}

Nephritis and nephrosis (590-594)

Cancer of stomach (151)

Bronchitis (500-502)

In the final column are the rates for all other causes of death at 25-54 years.

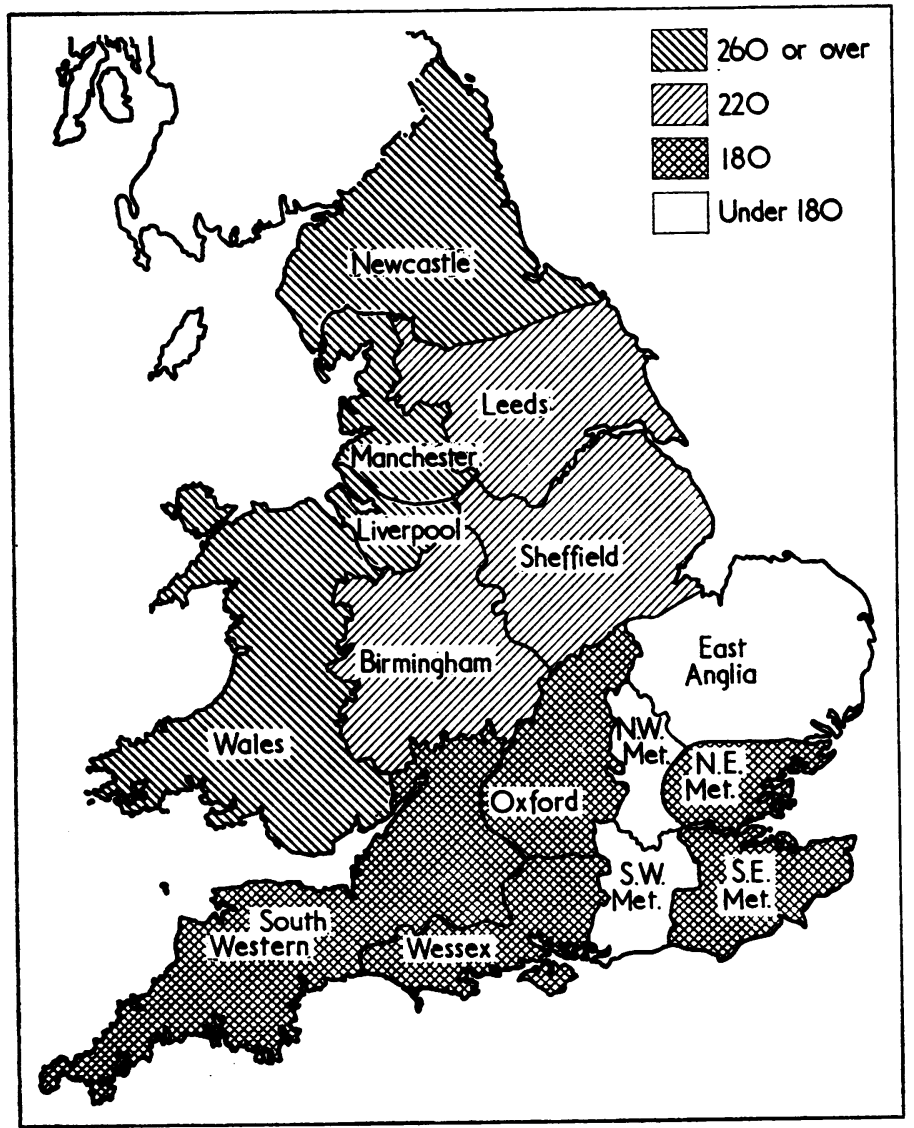

Fo. 6. Map of hospital regions of England and Wales showing distribution of death rates per million women aged 25-54 from all non-rheumatic heart disease, 1963-66. 
For clarity the 15 regions are ranked in descending order of the male rates for all congenital malformations as given in the first column of Table IV. The cardiovascular groups have highest rates in the first four regions of the North, North-West and Wales (the only exception being Birmingham for 'other heart'), and they have lowest rates in the last four regions and Wessex (exceptions being the North-East Metropolitan region for 'stroke' and 'other heart' and Leeds and the South-West regions for 'other heart'). A map for any of these causes would be hardly distinguishable from Fig. 4. This point is illustrated in Fig. 6 which shows the distribution of mortality due to non-rheumatic heart disease. Stomach cancer shows a similar distribution, being highest in the North and NorthWest (and in Wales at more advanced ages) and lowest in the last six regions and Wessex. For nephritis and bronchitis the correspondence with the malformation rates is less pronounced though for both causes the rates are above average in the first four regions and below average in the last four. astonishing, for a very clear-cut difference appears between the right- and left-hand parts of the table. Malformations of the neural tube (A-C) correlate very closely with mortality of women from each of the cardiovascular disease groups with coefficients all exceeding +0.8 whereas other malformations produce only insignificant negative coefficients. With nephritis, cancer of the stomach and bronchitis the coefficients with the nervous system malformations are between +0.62 and +0.75 whereas with other malformations they are negative or insignificant. The residual group of all other causes of death in women produces no correlations with either group of malformations except a small but not significant negative coefficient with 'other' malformations in female infants. It is to be noted that the size of the coefficients with the neural-tube malformations differs little between the sexes of the infants.

The conclusion to be drawn from these findings seems to be that whatever may be the environmental or genetic factors responsible for the regional

TABLE VII

CORRELATION COEFFICIENTS BETWEEN PRENATAL AND INFANT MORTALITY FROM CONGENITAL MAIFORMATIONS OF EACH SEX AND DEATH RATES OF WOMEN AGED 25-54 FROM CERTAIN CAUSES IN THE IS HOSPITAL REGIONS DURING 1963-66, DISTINGUISHING CENTRAL NERVOUS FROM OTHER MALFORMATIONS

\begin{tabular}{|c|c|c|c|c|}
\hline \multirow{3}{*}{$\begin{array}{l}\text { Causes of Death of Women aged 25-54 } \\
\text { (rates of dying in the same regions) }\end{array}$} & \multicolumn{4}{|c|}{ Congenital Malformations, Prenatal and Under 1 year } \\
\hline & \multicolumn{2}{|c|}{ Of Central Nervous System } & \multicolumn{2}{|c|}{ Of Other Parts of Body } \\
\hline & Males & Females & Males & Females \\
\hline $\begin{array}{l}\text { Chronic rheumatic heart disease (410-6) } \\
\text { Coronary disease. (420) } \\
\text { Other degenerative and hypertensive and ill-defined heart (421-443) } \\
\text { Vascular lesions of central nervous system (330-334) } \\
\text { Nephritis and nephrosis (590-594) } \\
\text { Cancer of stomach (151) } \\
\text { Bronchitis (500-502) }\end{array}$ & $\begin{array}{l}+0 \cdot 845 \\
+0 \cdot 844 \\
+0 \cdot 867 \\
+0 \cdot 840 \\
+0 \cdot 620 \\
+0 \cdot 747 \\
+0 \cdot 678\end{array}$ & $\begin{array}{l}+0.871 \\
+0.828 \\
+0.803 \\
+0.908 \\
+0.747 \\
+0.708 \\
+0.650\end{array}$ & $\begin{array}{r}0.000 \\
+0.033 \\
-0.174 \\
-0.111 \\
+0.159 \\
-0.052 \\
+0.123\end{array}$ & $\begin{array}{r}-0.361 \\
-0.250 \\
-0.167 \\
-0.311 \\
+0.003 \\
-0.067 \\
-0.267\end{array}$ \\
\hline All other causes & $+0 \cdot 174$ & +0.017 & +0.050 & -0.310 \\
\hline
\end{tabular}

For the group of all other causes no regional pattern is evident.

Evidence that some regional factor accounts for the correspondence between the frequencies of congenital malformation in infants and of certain diseases in the adult population would be strengthened if the correspondence appeared for specific types of malformation and not for the others. In Table VII correlation coefficients have been calculated between the regional rates for malformations of the central nervous system (groups A-C in Table III) and the deaths rates of women aged 25-54 from the causes identified in Table VI; and corresponding coefficients are shown for all other forms of congenital malformations. The outcome of the extensive calculations required for Table VII is unexpected and mortality pattern shown by cardiovascular diseases, with a falling trend of rates from north-west to southeast, some of the same factors also have pronounced effects on the incidence of congenital malformations of the central nervous system but not on other forms of malformation. In lesser degree this seems to apply also to nephritis, stomach cancer and bronchitis. The nature of the regional factors remains in doubt, but the findings of Morris and his co-workers on soft water as a factor tending to increase mortality from cardiovascular diseases in the large towns point to a water factor as being probably important, and it is conceivable that differing calcium contents of water supplies might account for the regional variations of C.N.S. malformations in Tables III and IV. 


\section{SUMMARY}

In 25 countries during 1961-65 the sex ratios of female to male rates of infant mortality attributed to congenital malformations were higher in Ireland, Scotland, England and Wales, the Netherlands and Canada than in any other country and were low in Scandinavia. Analysis according to the part of the body affected showed that the high rates arose from larger proportions of deaths from malformations of the neural tube and a greater excess of females in that group.

When England and Wales were divided into standard regions and conurbations the infant mortality of males in 1957-66 from all malformations combined were highest in the North and North-West and in Wales, and lowest in the East, South-East and South. Female rates exceeded those of males in Northern and North Midland regions, and South Wales and in the Merseyside and West Midland conurbations.

When prenatal deaths were combined with postnatal deaths at 0-1 year the rates per 1000 live and stillbirths in the Hospital Regions during 1963-66 were highest for both sexes in the Liverpool, Welsh, Manchester and Newcastle regions, and lowest for males in the western Metropolitan areas and Oxford, and for females in the Metropolitan areas. The downward trend in incidence from north-west to south-east is even more striking for the neural-tube malformations, and the sex ratio for these ranged from 1.4 to 2.4 . No regional trend appears, however, for other congenital malformations.

Death rates of women aged 25-54 from each group of cardiovascular diseases show a closely similar regional distribution to that for the neural-tube malformations, with correlation coefficients exceeding 0.8; nephritis, stomach cancer and bronchitis also show a similar pattern with correlations over 0.6. None of these causes shows any association with other kinds of malformation. Rates from all other diseases of women show no correlation with any form of malformation. It is concluded that there must be some factor, genetic or environmental, which affects at the same time the incidence of congenital malformations of the central nervous system and mortality of women from the diseases mentioned.

\section{REFERENCES}

Butler, N. R., and Bonham, D. C. (1963). Perinatal Mortality, 1st report. Livingstone, London.

CraWford, M. D., Gardner, M. J., and Morris, J. N. (1968). Mortality and hardness of local water supplies. Lancet, 1, 827, 1092.

GrEGG, N. MCA. (1941). Congenital cataract following German measles in the mother. Trans. Ophthal Soc. Aust., 3, 35.

Gentry, J. T., Parkhurst, E., and Bulin, G. V. (1959). Epidemiological study of congenital malformations in New York State. Amer. J. Publ. Hlth, 49, 497.

Laurence, K. M., Carter, C. O., and David, P. A. (1968). Major central nervous system malformations in South Wales. Brit. J. prev. soc. Med., 22, 146, 212.

Morris, J. N., Crawford, M. D., and Heady, J. A. (1961). Hardness of local water supplies and mortality from cardio-vascular disease. Lancet, 1, 860.

- - (1962). Ibid., 2, 506.

Smithels, R. W. (1962). The Liverpool congenital abnormalities registry. Devel. Med. Child. Neurol., $4,320$.

Stevenson, A. C., and Warnock, H. A. (1959). Observations on the results of pregnancies in women resident in Belfast. Ann. hum. Genet., 23, 382.

Stocks, P. (1947). Regional and local differences in cancer death rates. Studies in Medical and Population Subjects, No. 1. General Register Office, London.

- (1950). Cancer of the stomach in the large towns of England and Wales. Brit. J. Cancer, 4, 147.

Swan, C., MoOre, B., Mayo, H., and Black, G. H. B. (1943). Congenital defects in infants following infectious diseases during pregnancy. Med. J. Aust., 2, 201.

World HEALTH ORganisation (1967). Epidemiological and Vital Statistics Report, 20, 711. 